\title{
Prospective Science Teachers' Perception Related to Formative Assessment Approaches in Turkey
}

\author{
M. Diyaddin Yaşar \\ Correspondence: M. Diyaddin Yașar, Faculty of Education, Harran University, Şanlıurfa, Turkey.
}

Received: February 3, 2016

doi:10.11114/jets.v5i4.2190
Accepted: February 21, $2017 \quad$ Online Published: February 23, 2017

URL: https://doi.org/10.11114/jets.v5i4.2190

\begin{abstract}
In this study, it was aimed to investigate the perceptions and competences of prospective science teachers about formative assessment approaches. Qualitative case study methodology was used in the study. Research group consisted of 17 senior students of science education. As a data collection tool, a semi-structured "Formative Assessment Perception Interview Form" was used which was developed by the researcher. The data were collected by conducting a total of ten in-depth interviews, 8 with focus groups and another 2 as face -to-face. Collected data were subjected to content analysis. Study findings revealed that perceptions and competences of prospective science teachers on formative assessment approaches are very low and not sufficient. In particular, it was found out in this study that prospective science teachers are familiar with the definition and function of formative assessment approaches (12\%) at a low extent albeit; however, they are seriously deficient about for what purpose (7\% competence) they will use and choose them, how to prepare such approaches (3\% competence), how to interpret and score effects of the results for the learning-teaching process (2\% competence). Science teacher training curricula need to be revised in a way to give prospective teachers a training and preparation in practical, long-term and real learning-teaching environments for formative assessment approaches.
\end{abstract}

Keywords: formative assessment approaches, science education, science teacher training, Turkey

\section{Introduction}

Theories that dominated learning in the 20th century seem to be associationist and behaviourist learning, and they were replaced by social constructivism in the 21 st century (Shepart, 2000). The perspective, concepts and approaches to learning, teaching, and assessment seem to change as well as how learning takes place and views and theories related to learning change (Abell \& Siegel, 2011, Shepart, 2000). Measurement and assessment is also an important element of this change, leading to radical reforms in science education and science curricula. Therefore, measurement and assessment is of vital importance in secondary and tertiary science education and classes, for reporting on student learning and knowledge affecting students 'development on the basis of the curriculum as well as providing support to students' science learning (Lyon, 2013).

In Turkey, various innovations have been made both in science education and in structural and science curricula in order to be able to keep up with current developments and to keep up with the times. The school system in Turkey consists of three levels, $4+4+4$. The first level is primary education, the second level is secondary level-I and the third level is secondary level-II. Particularly in 2004, science curricula based on constructivist learning theories and student centered science-technology course curricula was adopted along with other learning theories. Then in 2013, science training curricula based on inquiry-based learning approach were developed. Thus, there have been significant changes in the measurement and assessment of science curricula. In science curricula, although classical measurement and assessment approaches are excluded, the main emphasis is on formative assessment approaches. Science teacher training program in Turkey consists of 8 semesters and lasts for 4 years. In general, the courses are divided into three parts: field and field training courses, pedagogical courses and general knowledge courses. Those who graduate from this curriculum, work as science teachers in secondary education level 1. In science teacher training program, measurement and assessment is offered as a pedagogical course in the third year. Among the knowledge and skills to be acquired by undergraduate students related to this course are the development and effective application of tools for multidimensional identification of students (observation, interview, portfolio, research papers, research projects, peer assessment, self-assessment, attitude scales etc (HEC, 2007). In parallel with this, it is seen that in the secondary-I science curricula, a measurement and assessment approach is adopted to provide continuous feedback to monitor students' improvement in the process, to guide them, to fix and eliminate learning difficulties and to support meaningful and permanent learning (MoNE, 2013). This 
gives priority to the evaluation of the learning process as much as the product. Besides classical measurement and assessment approaches, formative assessment approaches also need to be used effectively in science education. Thus, it can be said that in science curricula, assessment-centered learning environments are adopted. In assessment-centered learning environments (Abell \& Siegel, 2011), teachers apply formative assessment approaches to support learning, to help students become aware of and improve their thinking, and to provide information about education. In Turkey, as understood from the science teacher training curriculum and secondary-I science curricula, when a prospective science teacher graduates from the faculty of education, they must have sufficient knowledge and skills on formative assessment approaches and be fully equipped to graduate.

Science education promotes our knowledge or understanding of the need to organize and use effective and efficient measurement and assessment in science classes. However, there are very few studies that examine science teachers' measurement-assessment competences, knowledge, perceptions, etc (Lyon, 2013). In addition, many teachers do not feel sufficient about measuring and assessing, and need help to implement and make decisions based on measurement and assessment techniques in multiple and different types (Mertler \& Campbell, 2005). Thus, prospective science teachers' use of effective measurement and assessment approaches or activities in science education has a vital importance for the development and progress of science education (Lyon, 2013). Teacher training programs make a great effort to help teacher candidates acquire the knowledge and skills needed to be successful in their future careers (Yllmaz-Tüzün, 2008). Teacher candidates must graduate with the necessary and well-developed professional knowledge and skills. The more sufficient knowledge they leave with about measurement and assessment, the more confident they will be able to apply different types of measurement and assessment techniques after graduation (Yılmaz-Tüzün, 2008). In this research, it was aimed to examine the perceptions and competences of prospective science teachers towards formative assessment approaches. For this purpose; investigation was carried out on conceptions and competences of prospective science teachers related to formative assessment approaches such as performance assessment, portfolio, diagnostic branched tree, structured grid, word association tests, concept maps, interview and observation. Based on each of these identified formative assessment approaches, answer was sought for the following research questions:

1. What is the level of perceptions and competences of prospective science teachers for the definition/function of formative assessment approaches?

2. What is the level of perceptions and competences of prospective science teachers for the purposes of formative assessment approaches?

3. What is the level of perceptions and competences of prospective science teachers for the preparation of formative assessment approaches?

4. What is the level of perceptions and competences of prospective science teachers for the interpretation/scoring of results from formative assessment approaches?

\section{Method}

\subsection{Research Design}

This study was conducted as a case study, one of the qualitative research methods. Case studies are about in-depth description and analysis of a limited system or situation (Meriam, 2009; McMillan \& Schumacher, 2010).

\subsection{Participants}

The research was conducted with 17 (11 female and 6 male) senior grade science teacher candidates, selected by convenient sampling method, in 2014-2015 academic year.

\subsection{Data Collection Tool and Development and Implementation Process}

In this study, the "Formative Assessment Perception Interview Form" developed by the author was collected using semi-structured interview form. Before the interview form was developed, relevant literature and documents were reviewed. As a result of the related researches, interview questions about the study were prepared. The questions were presented to two experts who were experts in the field for their opinion. A draft interview form was prepared according to their opinions. The draft interview form was pilot interviewed with three prospective science teachers. Following examination of the interviews, the shortcomings found in the form were resolved and the form was finalized. The semi-structured interview form is composed of two parts: the first part briefly presents the purpose of the research and demographic data about the participants. The second part included the interview questions. The interview questions consist of 9 open-ended questions and probes under them.

By using the semi-structured interview form, in-depth interviews were held; face-to-face interviews with 2 senior grade prospective science teachers and 8 focus group interviews were conducted with 15 other participants. In total, 10 interviews were made with 17 prospective science teachers. The interviews were held at the author's office separately for 
each individual and group at the pre-scheduled time and date. The interviews lasted approximately 45 minutes to 1 hour and were recorded.

\subsection{Data Analysis}

Content analysis, which is a kind of qualitative data analysis, was conducted on the data obtained from the interviews. In the first content analysis, the data obtained from the interviews were transcribed. Then, the transcriptions were read and analyzed in detail. In the analysis of the data, first of all, the data obtained from the first 3 interviews were analyzed and main categories and codes were created. Then the same process was applied to the remaining interviews and obtained categories and codes were added to the initial list. As a result of the content analysis of all the interviews, 4 basic categories and their sub codes were formed as the description/function of, purpose of, preparation of and interpreting/scoring of results of the formative assessment approach. The first content analysis was completed by calculating the frequency and percentages of the categories and codes.

The interview data were reviewed and analyzed by the author a second time in order to ensure the consistency and reliability of the analysis data. The second content analysis was performed approximately 5 months after the initial content analysis. The first content analysis and the second content analysis were calculated for the percentage of matches. Agreement percentage was calculated by using the agreement percentage formula $\left(\mathrm{P}=\mathrm{N}_{\mathrm{a}} \mathrm{x} 100 / \mathrm{N}_{\mathrm{a}}+\mathrm{N}_{\mathrm{d}}\right)(\mathrm{Coll}$, 1986, p.512; Robson, 1893, p.222, cited by Türnüklü, 2000; Bakeman \& Gottman, 1997, p.60, cited by Türnüklü, 2000). Agreement percentage of $80 \%$ indicates that the results of qualitative data analysis are reliable (Keeves \& Sowden, 1994 , p.1469, cited by Türnüklü, 2000). In this study, the first and second content analysis agreement rate was $82.07 \%$ and the content analysis was found to be reliable. The results of the content analysis are presented in tables from 1 through 8 .

After the interview data content analysis, rubrics for each formative assessment approach were drawn up based on the literature to determine the competence levels of prospective science teachers in relation with the defined formative assessment approaches. The content analysis results obtained from the participants were compared with developed rubrics. As a result, competences of prospective science teachers related to formative assessment approach were referred with three codes Strong Competence (SC), Weak Competence (WC) and Incompetence (IC) and displayed in graphics (see figure through 1 to 9 ).

\section{Results}

In this section, findings are given about prospective science teachers' (PST) perceptions and competences related to formative assessment approaches (FAA).

\subsection{Perceptions and Competences of PSTs related to Performance Assessment (PA)}

The first category consists of definition and function (DF) of PA with six affiliated codes such as DF1 to DF6. It was seen that PST placed the most focus on DF1 and DF2 at 33.33\%. The second category includes Purpose (P) of PA and 13 codes are located under this category as P1to P13. PSTs were found to have the most emphasis on P1 code at $17.24 \%$. The third category consists of Preparation (Pr) of PA and under this category are 7 codes as Pr to Pr7. PSTs were found to have the most emphasis on Pr1 code AT 33.33\%. The fourth category, as shown in Table 1, is about Interpreting and Scoring (IS) results of PA, and under this category there are 11 codes as IS1 to IS11. Prospective science teachers were found to have the most emphasis on IS1 and IS2 codes at $16.66 \%$. 
Table 1. Perceptions of PSTs related to PA

\begin{tabular}{|c|c|c|c|}
\hline Codes & DF of PA & $\mathrm{f}$ & $\%$ \\
\hline DF1 & Through performance assignments, assessment of learners as a whole during the process. & 4 & 33,33 \\
\hline DF2 & Yielding a product through the project. & 4 & 33,33 \\
\hline DF3 & An approach that evaluates the practices / activities of the learners in the process. & 2 & 16,66 \\
\hline DF4 & The effort exerted by the learner for one semester. & 1 & 8,33 \\
\hline DF6 & I do not know & 1 & 8,33 \\
\hline \multirow[t]{2}{*}{ Subtotal } & & 12 & 100 \\
\hline & P of PA & & \\
\hline P1 & Ensuring learners to acquire the skill doing of research and inquiry. & 5 & 17,24 \\
\hline $\mathrm{P} 2$ & Ensuring learners to access knowledge. & 4 & 13,80 \\
\hline P3 & Ensuring learners to be responsible for their learning. & 3 & 10,35 \\
\hline P4 & Ensuring learners to acquire the skill of self-assessment. & 2 & 6,90 \\
\hline P5 & Identifying and increasing interest and curiosity of learners. & 2 & 6,90 \\
\hline P6 & Ensuring learners to develop scientific process skills. & 2 & 6,90 \\
\hline P7 & Identifying and developing learners' psycho-motor skills. & 2 & 6,90 \\
\hline P8 & Ensuring development of learners' responsibility consciousness. & 2 & 6,90 \\
\hline P9 & Ensuring development of learners' cognitive development. & 1 & 3,50 \\
\hline P10 & Ensuring increase of student self-confidence. & 1 & 3,50 \\
\hline P11 & Ensuring learners' socialization. & 1 & 3,50 \\
\hline $\mathrm{P} 12$ & Ensuring identification and development of students' affective skills. & 1 & 3,50 \\
\hline $\mathrm{P} 13$ & I do not know. & 3 & 10,35 \\
\hline \multirow[t]{2}{*}{ Subtotal } & & 29 & 100 \\
\hline & Pr of PA & f & $\%$ \\
\hline Pr1 & $\begin{array}{l}\text { Different performance tasks / assignments to prepare learners for research are prepared and } \\
\text { assigned to them. }\end{array}$ & 6 & 33,33 \\
\hline $\operatorname{Pr} 2$ & A form is prepared that includes the work done during the process. & 2 & 11,11 \\
\hline $\operatorname{Pr} 3$ & A problem about daily life is given to students as a task. & 2 & 11,11 \\
\hline $\operatorname{Pr} 4$ & In performance tasks, assessment criteria are determined. & 2 & 11,11 \\
\hline $\operatorname{Pr} 5$ & Students are aware of the assessment criteria. & 2 & 11,11 \\
\hline Pr6 & Student developments are monitored. & 1 & 5,55 \\
\hline $\operatorname{Pr} 7$ & I do not know. & 3 & 16,66 \\
\hline \multirow[t]{2}{*}{ Subtotal } & & 18 & 100 \\
\hline & IS results of PA & & \\
\hline IS1 & Results are interpreted and scored according to some predetermined criteria. & 4 & 16,66 \\
\hline IS2 & Weekly interviews / short meetings are held to interpret and score the results. & 4 & 16,66 \\
\hline IS3 & Results are interpreted and scored according to the resulting product. & 3 & 12,5 \\
\hline IS4 & Results are interpreted and scored according to the general trend during the process. & 2 & 8,33 \\
\hline IS5 & Results are interpreted and scored according to the student effort in the process. & 2 & 8,33 \\
\hline IS6 & The process is observed and the results are interpreted and scored. & 1 & 4,17 \\
\hline IS7 & Results are interpreted and scored by making regular checks. & 1 & 4,17 \\
\hline IS8 & Results are interpreted and scored according to students' diaries. & 1 & 4,17 \\
\hline IS9 & Self-assessments are made and the results are interpreted and scored. & 1 & 4,17 \\
\hline IS10 & Peer evaluation is done and the results are interpreted and scored. & 1 & 4,17 \\
\hline IS11 & I do not know how to interpret and score the results. & 4 & 16,66 \\
\hline Subtotal & & 24 & 100 \\
\hline
\end{tabular}

In parallel with Table 1, competence of prospective science teachers for performance assessment are given below in Figure 1. As seen in Figure 1, according to the perception of prospective science teachers, they have $80 \%$ of weak competence and $20 \%$ of incompetence for DF, which is the first category of performance assessment. As for P, which is the second category under performance assessment, they have $70 \%$ weak competence and $30 \%$ incompetence. Thirdly, it is seen that participants have $70 \%$ weak competence and $30 \%$ incompetence for Pr of performance assessment. Lastly in IS, the last category of PA, it was found out that the participants have $60 \%$ weak competence and $40 \%$ incompetence. 


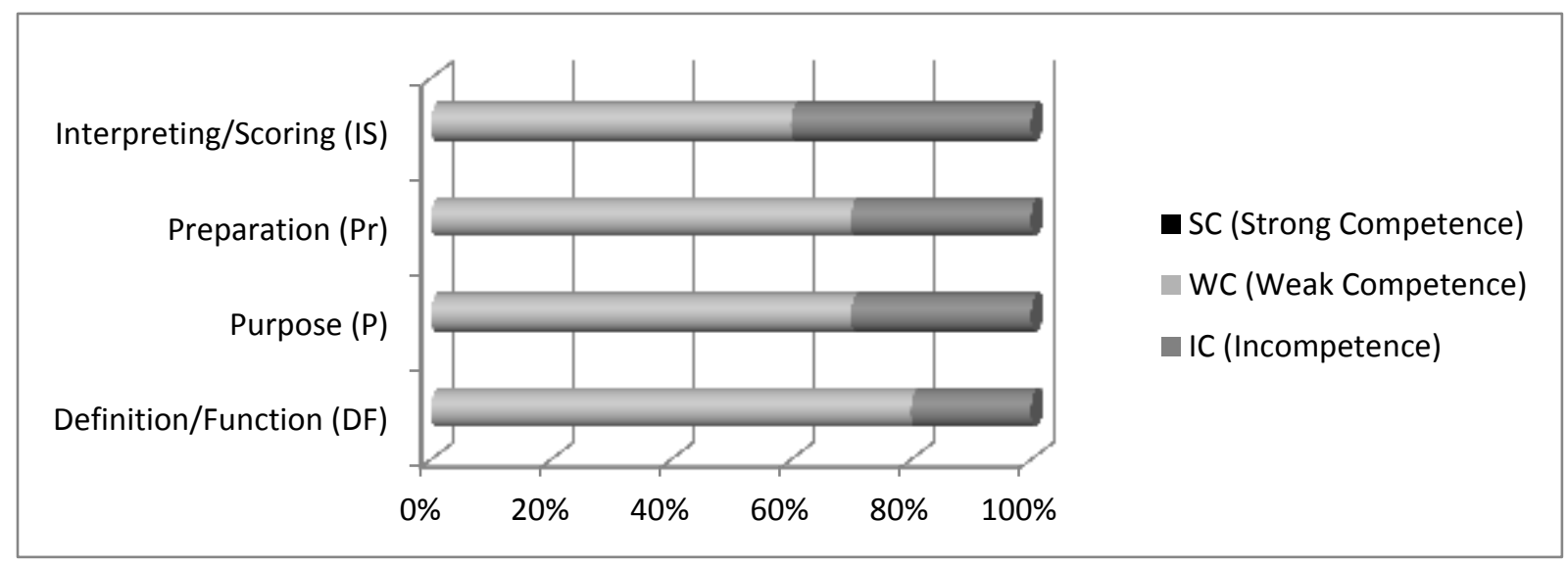

Figure 1. Competence levels of PSTs for PA

\subsection{Perceptions and Competences of PSTs Related to Portfolio (Po)}

First category is about DF of Portfolio (Po) with five codes under such as DF toDF5. It was seen that PSTs placed the most focus on DF1 with $69,23 \%$. The second category includes P of Po and 18 codes are located under this category as P1 to P18. Prospective science teachers were found to have the most emphasis on P1 code with $16 \%$. The third category consists of Pr of Po and under this category are 7 codes as Pr1 toPr7. Prospective science teachers were found to have the most emphasis on Pr1 code with 34,78\%. The fourth category, as shown in Table 1, is about IS results of Po, and under this category there are 12 codes as IS1 to IS12. Prospective science teachers were found to have the most emphasis on IS12 with $23,53 \%$, followed by IS1 with $17,65 \%$.

In parallel to Table 2, competences of prospective science teachers for portfolio are given Figure 2. As seen in the Figure 2 , according to the perceptions of science teachers, they have $90 \%$ of weak competence and $10 \%$ of incompetence for $\mathrm{DF}$, which is the first category of portfolio. As for $\mathrm{P}$, which is the second category under portfolio, they have $70 \%$ weak competence and 30\% incompetence. Thirdly, it is seen that participants have $70 \%$ weak competence and $30 \%$ incompetence for Pr of portfolio. Lastly in IS, the last category of Po, it was found out that the participants have 30\% weak competence and $70 \%$ incompetence. 
Table 2. Perceptions of PSTs related to Po

\begin{tabular}{|c|c|c|c|}
\hline Codes & DF of Po & f & $\%$ \\
\hline DF1 & $\begin{array}{l}\text { A file which includes all assignments, projects, etc. given to the learners during the education and } \\
\text { instruction period. }\end{array}$ & 9 & 69,23 \\
\hline DF2 & It is a collection of performance tasks. & 1 & 7,70 \\
\hline DF3 & It is an assessment approach that involves the assessment of the product generated. & 1 & 7,70 \\
\hline DF4 & It is an annual assignment given to learners. & 1 & 7,70 \\
\hline DF5 & An assessment approach without process evaluation. & 1 & 7,70 \\
\hline Subtotal & & 13 & 100 \\
\hline \multicolumn{4}{|c|}{$\mathrm{P}$ of Po } \\
\hline P1 & Ensuring to better recognize learners relating to information, skills, attitudes, and so on. & 4 & 16,00 \\
\hline P2 & Following learner's development through the process. & 3 & 12,00 \\
\hline P3 & Identifying learners' information about a topic. & 2 & 8,00 \\
\hline P4 & Ensuring learners to identify missing aspects of their knowledge about a topic. & 1 & 4,00 \\
\hline P5 & Ensuring study in cooperative groups. & 1 & 4,00 \\
\hline P6 & Determining learners' interest and attitude towards lesson. & 1 & 4,00 \\
\hline P7 & Providing learning experiences or experiences. & 1 & 4,00 \\
\hline P8 & Increasing the success of learners. & 1 & 4,00 \\
\hline P9 & Ensuring learners to build self-consciousness. & 1 & 4,00 \\
\hline P10 & Ensuring learners to be responsible for their learning. & 1 & 4,00 \\
\hline P11 & Ensuring learners to become active. & 1 & 4,00 \\
\hline P12 & Ensuring learners to gain self-assessment awareness. & 1 & 4,00 \\
\hline P13 & Ensuring learners to improve their scientific process skills. & 1 & 4,00 \\
\hline P14 & Determining the level of learners or their readiness. & 1 & 4,00 \\
\hline P15 & Determining and eliminating the misconceptions of learners. & 1 & 4,00 \\
\hline P16 & Ensuring learners to acquire research skills. & 1 & 4,00 \\
\hline P17 & Development of cognitive, affective and psychomotor skills of the learners. & 1 & 4,00 \\
\hline P18 & I do not know. & 2 & 8,00 \\
\hline Subtotal & & 25 & 100 \\
\hline \multicolumn{4}{|c|}{ Pr of Po } \\
\hline Pr1 & $\begin{array}{l}\text { The portfolio should include homework, assignments, projects and activities that learners have } \\
\text { prepared. }\end{array}$ & 8 & 34,78 \\
\hline $\operatorname{Pr} 2$ & Learners need to create a portfolio. & 6 & 26,09 \\
\hline Pr3 & The portfolio should include information about learners and their families. & 2 & 8,70 \\
\hline $\operatorname{Pr} 4$ & The portfolio should include directions for specific tasks. & 1 & 4,35 \\
\hline Pr5 & $\begin{array}{l}\text { In preparing the portfolio, it is necessary to carry out certain planning which shows gradual } \\
\text { progress. }\end{array}$ & 1 & 4,35 \\
\hline Pr6 & As the laboratory report is prepared, a portfolio must be prepared. & 1 & 4,35 \\
\hline Pr7 & I do not know. & 4 & 17,4 \\
\hline Subtotal & & 23 & 100 \\
\hline \multicolumn{4}{|c|}{ IS results of Po } \\
\hline IS1 & $\begin{array}{l}\text { Results are interpreted and scored according to the products, studies, assignments, and activities, } \\
\text { etc. attached to the file. }\end{array}$ & 3 & 17,65 \\
\hline IS2 & Results are interpreted and scored by looking at what the learners have done in the process. & 1 & 5,88 \\
\hline IS3 & Results are interpreted and scored according to some predetermined criteria. & 1 & 5,88 \\
\hline IS4 & Results are interpreted and scored according to the success of the learner in the general trend. & 1 & 5,88 \\
\hline IS5 & Some stages are determined and the results are interpreted and scored accordingly. & 1 & 5,88 \\
\hline IS6 & Results are interpreted and scored according to the learners' expressions, verbally and in writing. & 1 & 5,88 \\
\hline IS7 & Results are interpreted and scored by observing the progress in the process. & 1 & 5,88 \\
\hline IS8 & A certain scoring system is determined and the results are interpreted and scored accordingly. & 1 & 5,88 \\
\hline IS9 & Results are interpreted and scored according to learners' diaries. & 1 & 5,88 \\
\hline IS10 & Self-evaluation is performed and the results are interpreted and scored accordingly. & 1 & 5,88 \\
\hline IS11 & Peer evaluation is performed and the results are interpreted and scored accordingly. & 1 & 5,88 \\
\hline IS12 & I do not know & 4 & 23,53 \\
\hline Subtotal & & 17 & 100 \\
\hline
\end{tabular}




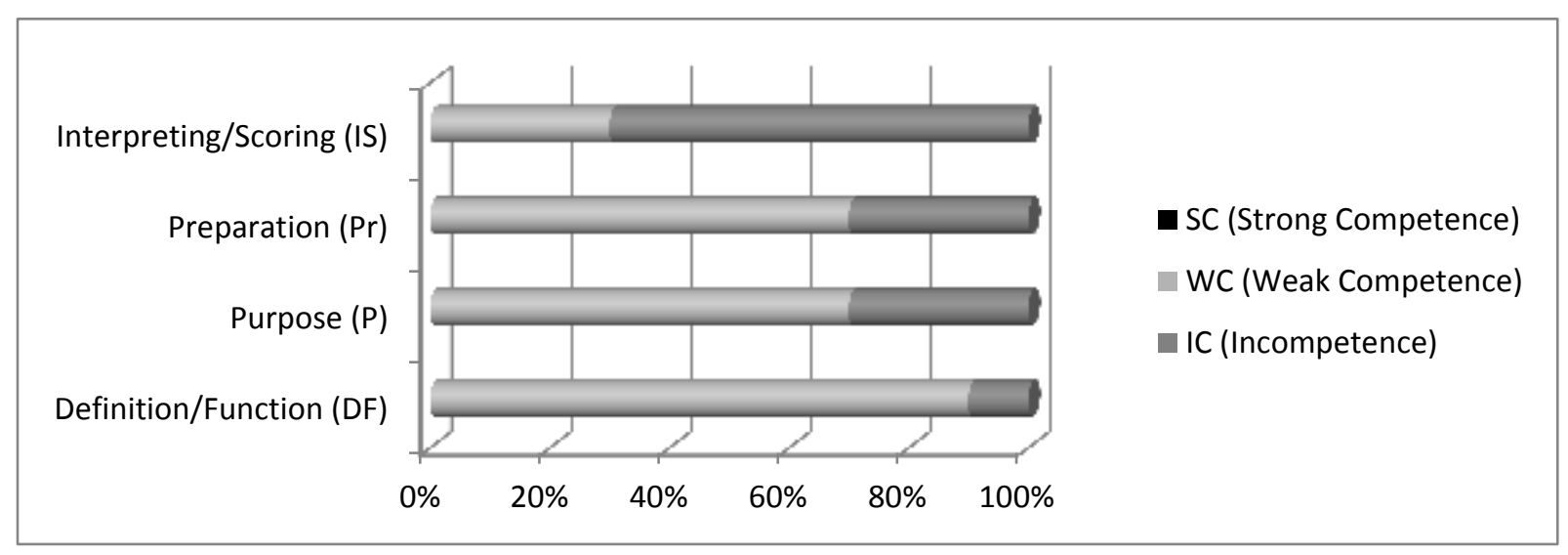

Figure 2. Competence levels of PSTs for Po

\subsection{Perceptions and Competences of PSTs related to Concept Maps (CM)}

The first category consists of DF of concept map with four affiliated codes such as DF1 to DF4. It was seen that PSTs placed the most focus on DF1 at 36,84\%. The second category includes P of CM, 10 codes are located under this category as P1 to P10. Prospective science teachers were found to have the most emphasis on P1 code at 23,08\%. The third category consists of $\operatorname{Pr}$ of CM and under this category are 9 codes as $\operatorname{Pr} 1$ to $\operatorname{Pr} 9$. Prospective science teachers were found to have the most emphasis on Pr1 code at $25 \%$. The fourth category, as shown in Table 3 , is about IS of results of $\mathrm{CM}$, and under this category there are 6 codes as IS1 to IS6. Prospective science teachers were found to have the most emphasis on IS6 code at $33,33 \%$, followed by IS1 at $22,22 \%$.

In parallel with Table 3, competences of prospective science teachers for concept maps are given in Figure 3. As the figure displays, according to the prospective science teachers, they have $80 \%$ of strong competence and $20 \%$ of weak competence for $\mathrm{DF}$, which is the first category of $\mathrm{CM}$. As for $\mathrm{P}$, which is the second category under $\mathrm{CM}$, they have $30 \%$ strong competence, $50 \%$ weak competence, and $20 \%$ incompetence. Thirdly, participants have $30 \%$ strong competence and $50 \%$ weak competence and $20 \%$ incompetence for Pr of concept maps. Lastly in IS, the last category of CM, it was found out that the participants have $40 \%$ weak competence and $60 \%$ incompetence. 
Table 3. Perceptions of PSTs related to CM

\begin{tabular}{|c|c|c|c|}
\hline Codes & DF of CM & $\mathrm{f}$ & $\%$ \\
\hline DF1 & It is a course material used at the end or before the subject. & 7 & 36,84 \\
\hline DF2 & It is an approach that gives concepts related to the subject and clarifies the connection between them. & 6 & 31,58 \\
\hline DF3 & It is an approach that provides the main summary, idea or essentials of a topic. & 4 & 21,05 \\
\hline DF4 & $\begin{array}{l}\text { It is an approach in which the concepts are written on the board and the (conceptual) network among them is } \\
\text { drawn. }\end{array}$ & 2 & 10,53 \\
\hline \multirow[t]{2}{*}{ Subtotal } & & 19 & 100 \\
\hline & $\mathrm{P}$ of $\mathrm{CM}$ & & \\
\hline $\mathrm{P} 1$ & To present the relationship between concepts. & 6 & 23,08 \\
\hline $\mathrm{P} 2$ & To provide narration and summary of the topic. & 5 & 19,23 \\
\hline $\mathrm{P} 3$ & To provide conceptual learning. & 4 & 15,39 \\
\hline $\mathrm{P} 4$ & To identify and eliminate misconceptions. & 3 & 11,54 \\
\hline P5 & To measure the knowledge of learners. & 3 & 11,54 \\
\hline P6 & To measure and determine whether the learner listens to the lecture. & 1 & 3,85 \\
\hline P7 & To determine whether learners come prepared for the lesson. & 1 & 3,85 \\
\hline P8 & To determine and measure the attentiveness and attention of the learner. & 1 & 3,85 \\
\hline P9 & To eliminate lack of knowledge of learners. & 1 & 3,85 \\
\hline $\mathrm{P} 10$ & To establish the relationship between the previous knowledge and the new knowledge to be learned. & 1 & 3,85 \\
\hline \multirow[t]{2}{*}{ Subtotal } & & 26 & 100 \\
\hline & Pr of $\mathrm{CM}$ & & \\
\hline Pr1 & $\begin{array}{l}\text { It is prepared as an approach in which a concept is given a sub-concepts are identified and the relationship } \\
\text { between them is elicited. }\end{array}$ & 7 & 25,00 \\
\hline $\operatorname{Pr} 2$ & Relationships between the arrows and the concepts are provided. & 4 & 14,29 \\
\hline Pr3 & It is an approach in which concepts and the boxes are provided for learners and the map is prepared. & 3 & 10,71 \\
\hline $\operatorname{Pr} 4$ & The relationship on the arrows must be determined. & 3 & 10,71 \\
\hline $\operatorname{Pr} 5$ & It is an approach in which concepts on the subject are asked of learners in the e & 2 & 7,14 \\
\hline Pr6 & $\begin{array}{l}\text { It is an approach prepared in a way to create the network/connection among concepts (to create the conceptual } \\
\text { network). }\end{array}$ & 2 & 7,14 \\
\hline $\operatorname{Pr} 7$ & $\begin{array}{l}\text { It is an approach in which learners are asked to create the concept map before providing them the concept and } \\
\text { boxes. }\end{array}$ & 2 & 7,14 \\
\hline Pr8 & It is prepared by writing the concepts in empty boxes. & 1 & 3,57 \\
\hline $\operatorname{Pr} 9$ & I do not know. & 4 & 14,29 \\
\hline \multirow[t]{2}{*}{ Subtotal } & & 28 & 100 \\
\hline & IS results of CM & & \\
\hline IS1 & $\begin{array}{l}\text { Results are interpreted and scored by giving right points to correct conceptions and wrong points to incorrect } \\
\text { conceptions. }\end{array}$ & 4 & 22,22 \\
\hline IS2 & $\begin{array}{l}\text { Results are interpreted and scored according to accurate determination and account of the relation between } \\
\text { concepts. }\end{array}$ & 3 & 16,67 \\
\hline IS3 & Results are interpreted and scored by identifying a certain score in each box. & 2 & 11,11 \\
\hline IS4 & Results are interpreted and scored according to correct determination of the relationship on the arrows. & 2 & 11,11 \\
\hline IS5 & Results are interpreted and scored by right determination of the arrow direction. & 1 & 5,56 \\
\hline IS6 & I do not know. & 6 & 33,33 \\
\hline \multicolumn{2}{|c|}{ Subtotal } & 18 & 100 \\
\hline
\end{tabular}

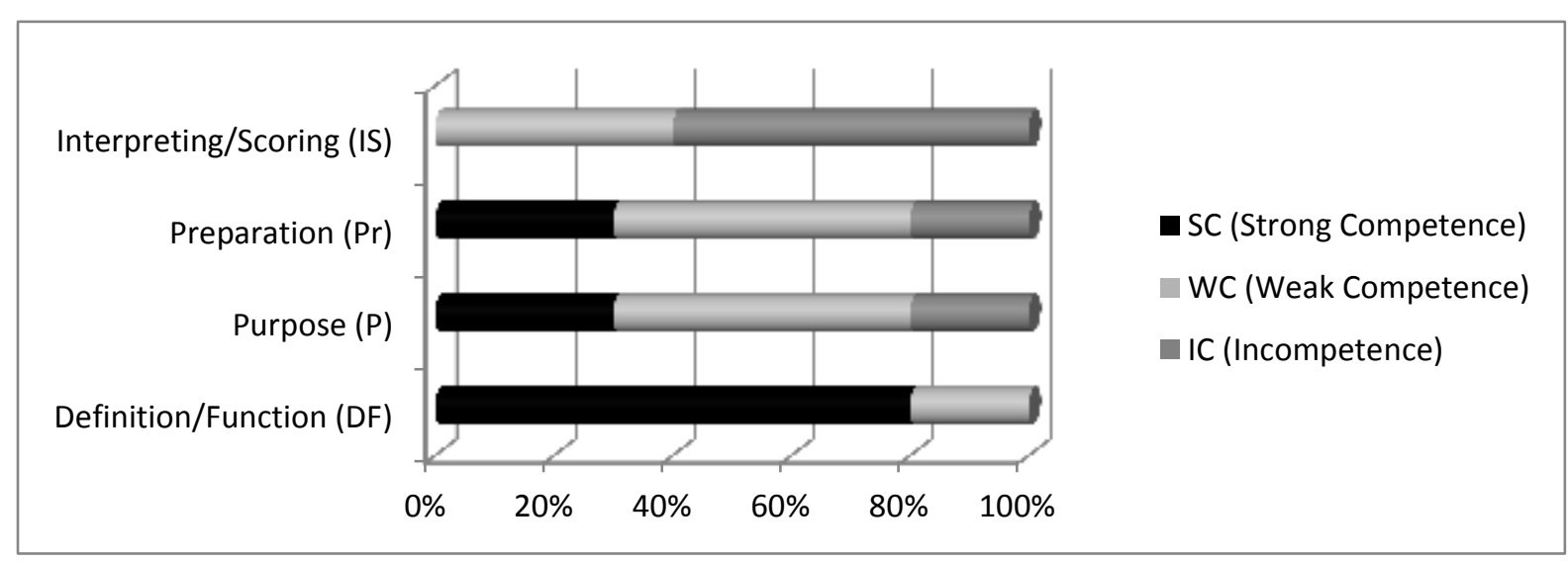

Figure 3. Competence levels of PSTs for concept maps

\subsection{Perceptions and Competences of PSTs related to Diagnostic Branched Tree (DBT)}

The first category consists of DF of DBT with 2 codes under it as DF1 and DF2. PSTs placed the most focus on DF1 at $60 \%$. The second category includes $\mathrm{P}$ of DBT and 7 codes are located under this category as P1 to P7. Prospective 
science teachers were found to have the most emphasis on P1 and P7 at 31,25\%. The third category consists of Pr of DBT and under this category are 6 codes as $\operatorname{Pr} 1$ to Pr6. Prospective science teachers were found to have the most emphasis on $\operatorname{Pr} 1$ and Pr6 at 28,57\%. The fourth category is about IS results of DBT, and under this category there are 3 codes, IS1, IS2, and IS3. Prospective science teachers were found to have the most emphasis on IS3 at $42,86 \%$, followed by IS1 and IS2 at $28,57 \%$, respectively.

Table 4. Perceptions of PSTs related to DBT

\begin{tabular}{|c|c|c|c|}
\hline Codes & DF of DBT & f & $\%$ \\
\hline DF1 & It is an approach in which true or false statements follow the questions and exits are involved in the end. & 6 & 60,00 \\
\hline DF2 & I do not know. & 4 & 40,00 \\
\hline \multirow[t]{2}{*}{ Subtotal } & & 10 & 100 \\
\hline & $\mathrm{P}$ of DBT & & \\
\hline P1 & It is about identifying correcting learners' misconceptions. & 5 & 31,25 \\
\hline P2 & It is about providing the conceptual learning. & 2 & 12,5 \\
\hline P3 & It ensures finding of the right answer by reasoning and questioning of students. & 1 & 6,25 \\
\hline P4 & It determines whether the student has the master of the subject. & 1 & 6,25 \\
\hline P5 & It provides the the relationship between concepts. & 1 & 6,25 \\
\hline P6 & It develops students' ability to make decisions. & 1 & 6,25 \\
\hline P7 & I do not know. & 5 & 31,25 \\
\hline \multirow[t]{2}{*}{ Subtotal } & & 16 & 100 \\
\hline & Pr of DBT & & \\
\hline Pr1 & It is the questionnaire in which true-false statements are followed with arrows and exits are involved in the end. & 4 & 28,57 \\
\hline $\operatorname{Pr} 2$ & $\begin{array}{l}\text { It is the questionnaire in which a problem is involved in every step followed by subsequent questions with yes or } \\
\text { no statement. }\end{array}$ & 2 & 14,29 \\
\hline $\operatorname{Pr} 3$ & It is the questionnaire in which the next stage is achieved according to the right or wrong path selected. & 2 & 14,29 \\
\hline $\operatorname{Pr} 4$ & It is the questionnaire in which both true and false conceptions are involved at every. & 1 & 7,14 \\
\hline $\operatorname{Pr} 5$ & It is a questionnaire in which each arrow leads to a box. & 1 & 7,14 \\
\hline Pr6 & I do not know. & 4 & 28,57 \\
\hline \multirow[t]{2}{*}{ Subtotal } & & 14 & 100 \\
\hline & IS results of DBT & & \\
\hline IS1 & Results are interpreted and scored according to the exit point/departure point. & 4 & 28,57 \\
\hline IS2 & Results are interpreted and scored according to the number of right or wrong answers for each question. & 4 & 28,57 \\
\hline IS3 & I do not know. & 6 & 42,86 \\
\hline \multicolumn{2}{|c|}{ Subtotal } & 14 & 100 \\
\hline
\end{tabular}

In parallel with Table 4, competences of prospective science teachers for DBTs are given in Figure 4. As displayed in Figure 4, according to the prospective science teachers, they have $60 \%$ of weak competence and $40 \%$ of incompetence for DF, which is the first category of DBT. As for P, which is the second category under DBT, they have 50\% weak competence, $50 \%$ incompetence. Thirdly, participants have $60 \%$ weak competence and $40 \%$ incompetence for Pr of DBT. Lastly in IS, the last category of DBT, it was found out that the participants have $50 \%$ weak competence and $50 \%$ incompetence.

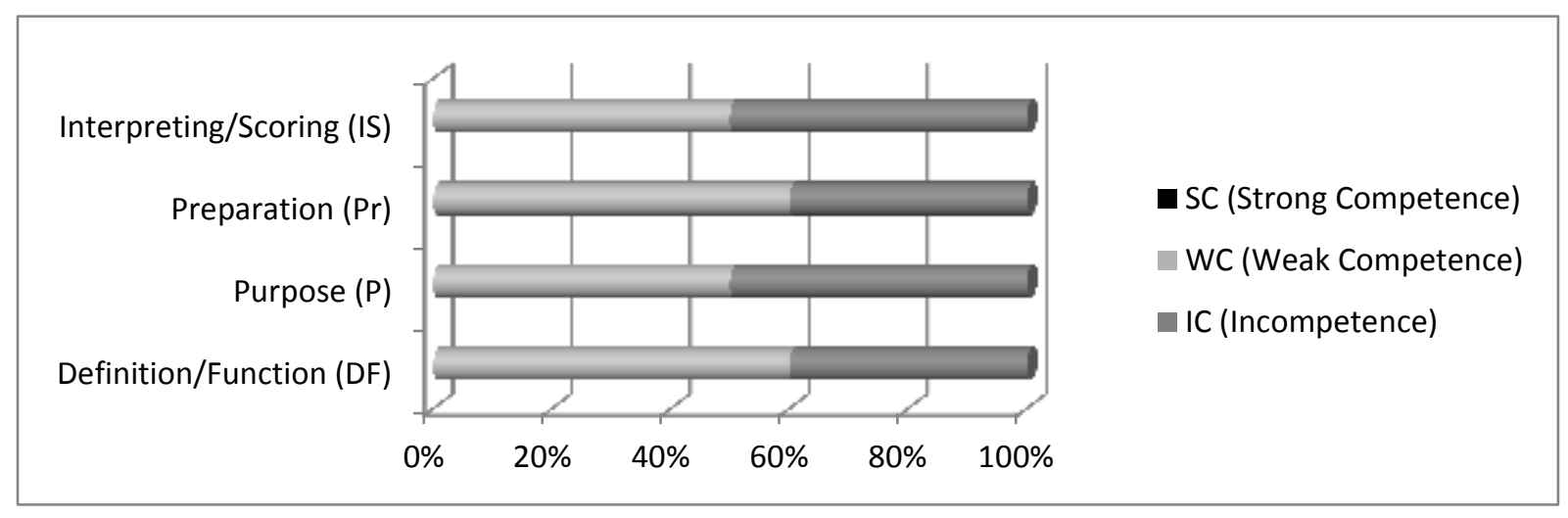

Figure 4. Competence levels of PSTs for DBT

\subsection{Perceptions and Competences of PSTs related to Structured Grid (SD)}

The first category consists of DF of SG with 6 codes under it as DF1 to DF6. PSTs placed the most focus on DF6 and DF1 at $46,15 \%$ and 23,08\%, respectively. The second category includes P of SG and 6 codes are located under this category as P1 toP6. Prospective science teachers were found to have the most emphasis on P6 at 58,33\%, followed by P1, P2, P3, P4, and P5, respectively. The third category consists of Pr of SG and under this category are 9 codes as Pr1 to Pr9. Prospective science teachers were found to have the most emphasis on $\operatorname{Pr} 9$ at $35 \%$, followed by $\operatorname{Pr} 1$ at $20 \%$. The 
fourth category is about IS results of SG, and under this category there are 3 codes, IS1, IS2, and IS3. Prospective science teachers were found to have the most emphasis on IS3 at 53,85\%, followed by IS1 at 23,08\%.

Table 5. Perceptions of PSTs related to SG

\begin{tabular}{|c|c|c|c|}
\hline Codes & DF of SG & $\mathrm{f}$ & $\%$ \\
\hline DF1 & $\begin{array}{l}\text { It is the questionnaire in which there are boxes/words/concepts/images in tables on top and questions in the } \\
\text { bottom. }\end{array}$ & 3 & 23,08 \\
\hline DF2 & It is the questionnaire in which there are gaps in the table to be filled in. & 1 & 7,69 \\
\hline DF3 & It is the questionnaire in which there are questions on top and answers in the bottom. & 1 & 7,69 \\
\hline DF4 & It is the questionnaire with more than one answer. & 1 & 7,69 \\
\hline DF5 & It is the questionnaire in which there are boxes. & 1 & 7,69 \\
\hline DF6 & I do not know & 6 & 46,15 \\
\hline \multirow[t]{2}{*}{ Subtotal } & & 13 & 100 \\
\hline & $\mathrm{P}$ of $\mathrm{SG}$ & & \\
\hline $\mathrm{P} 1$ & It helps the student find the right answer by questioning. & 1 & 8,33 \\
\hline $\mathrm{P} 2$ & It measures the knowledge level of students. & 1 & 8,33 \\
\hline P3 & It provides the conceptual learning. & 1 & 8,33 \\
\hline P4 & It builds up the relationship between concepts. & 1 & 8,33 \\
\hline P5 & It ensures classification of concepts. & 1 & 8,33 \\
\hline P6 & I do not know & 7 & 58,33 \\
\hline \multirow[t]{2}{*}{ Subtotal } & & 12 & 100 \\
\hline & Pr of SG & & \\
\hline Pr1 & $\begin{array}{l}\text { It is the questionnaire in which answers (concepts, words, pictures, etc.) are first placed into boxes/tables, and } \\
\text { then questions are asked. }\end{array}$ & 4 & 20,00 \\
\hline $\operatorname{Pr} 2$ & It is the questionnaire in which the number of boxes is given by the number of questions asked. & 2 & 10,00 \\
\hline $\operatorname{Pr} 3$ & It is the questionnaire which asks more than one question. & 2 & 10,00 \\
\hline Pr4 & $\begin{array}{l}\text { It is the questionnaire with a number of options, unlike the multiple-choice questionnaire, and decreased luck } \\
\text { factor. }\end{array}$ & 1 & 5,00 \\
\hline $\operatorname{Pr} 5$ & It is the questionnaire with boxes more than the number of questions. & 1 & 5,00 \\
\hline Pr6 & $\begin{array}{l}\text { It is the questionnaire in which the student determines the appropriate response to each question according to } \\
\text { boxes. }\end{array}$ & 1 & 5,00 \\
\hline $\operatorname{Pr} 7$ & It is the questionnaire in which some of the boxes are the wrong answers to the other questions. & 1 & 5,00 \\
\hline $\operatorname{Pr} 8$ & It is the questionnaire in which tables and spaces are provided for students to fill. & 1 & 5,00 \\
\hline Pr9 & I do not know & 7 & 35,00 \\
\hline \multirow[t]{2}{*}{ Subtotal } & & 20 & 100 \\
\hline & IS results of SG & & \\
\hline IS1 & Results are interpreted and scored by the number of boxes filled in correctly. & 3 & 23,08 \\
\hline IS2 & Results are interpreted and scored by giving full points to those answering the questions correctly. & 1 & 7,69 \\
\hline IS3 & I do not know & 7 & 53,85 \\
\hline \multicolumn{2}{|l|}{ Subtotal } & 13 & 100 \\
\hline
\end{tabular}

In parallel with Table 5, competences of prospective science teachers for SGs are given in Figure 5. As seen in Figure 5, according to the prospective science teachers, they have $30 \%$ of weak competence $70 \%$ of incompetence for DF, which is the first category of SG. As for P, which is the second category under structured grid, they have $30 \%$ weak competence and $70 \%$ incompetence. Thirdly, participants have $40 \%$ weak competence and $60 \%$ incompetence for Pr of SG. Lastly in IS, the last category of SG, it was found out that the participants have $30 \%$ weak competence and $70 \%$ incompetence.

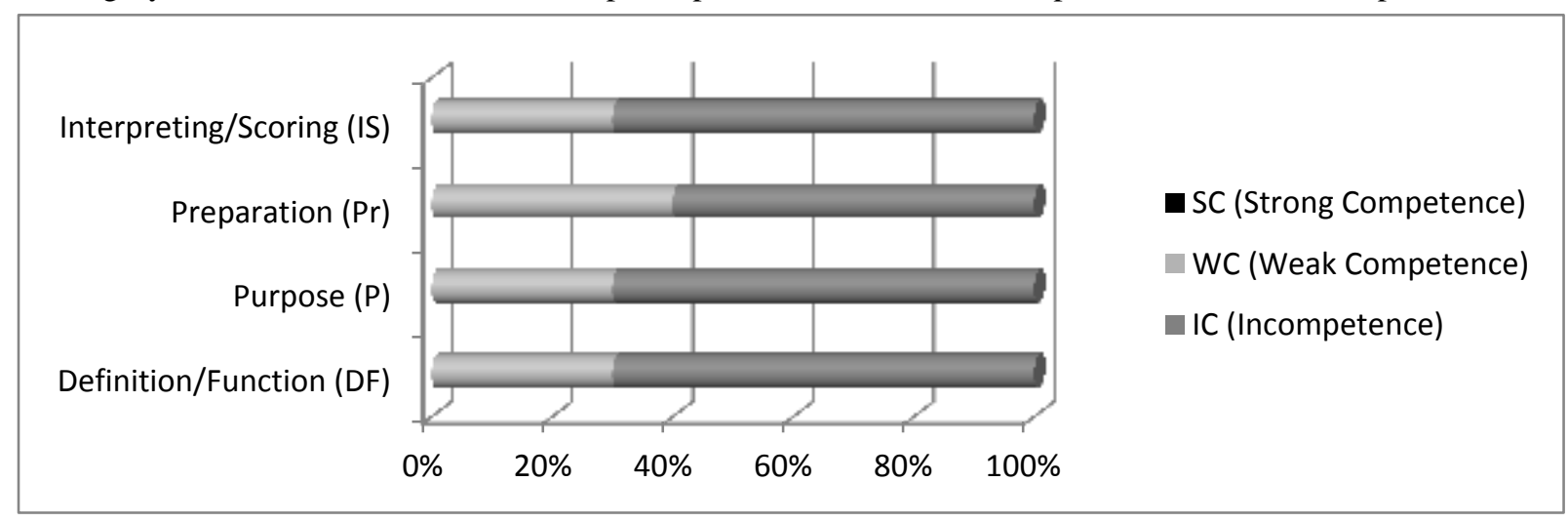

Figure 5. Competence levels of PSTs for SG 


\subsection{Perceptions and Competences of PSTs related to Word Association Tests (WATs)}

The first category consists of DF of WAT with 4 codes under it from DF1 to DF4. PSTs placed the most focus on DF4 and DF1 at 46,47\% and $40 \%$, respectively. The second category includes P of WAT and 4 codes are located under this category as P1 to P4. Prospective science teachers were found to have the most emphasis on P4 at 72,73\%, followed by P1, P2, and P3, respectively at 9,09\%. The third category consists of Pr of WAT and under this category are 3 codes as $\operatorname{Pr} 1$ to Pr3. Prospective science teachers were found to have the most emphasis on $\operatorname{Pr} 3$ at $70 \%$, followed by $\operatorname{Pr} 1$ at $20 \%$. The fourth category is about IS results of WAT and under this category there are 2 codes as IS1 and IS2. Prospective science teachers were found to have the most emphasis on IS 2 at $80 \%$, followed by IS 1 at $20 \%$.

Table 6. Perceptions of PSTs related to WAT

\begin{tabular}{|c|c|c|c|}
\hline Codes & DF of WAT & $\mathrm{f}$ & $\%$ \\
\hline DF1 & It is the questionnaire which is the same as pairing tests. & 6 & 40 \\
\hline DF2 & It is the questionnaire by which associations in students' minds are investigated for a given word or concept. & 1 & 6,67 \\
\hline DF3 & It is the questionnaire used to check preliminary information. & 1 & 6,67 \\
\hline DF4 & I do not know. & 7 & 46,47 \\
\hline Subtotal & & 15 & 100 \\
\hline \multicolumn{4}{|c|}{ P of WAT } \\
\hline $\mathrm{P} 1$ & It provides the conceptual learning. & 1 & 9,09 \\
\hline $\mathrm{P} 2$ & It measures the level of knowledge. & 1 & 9,09 \\
\hline P3 & It identifies and fixes misconceptions. & 1 & 9,09 \\
\hline P4 & I do not know. & 8 & 72,73 \\
\hline Subtotal & & 11 & 100 \\
\hline \multicolumn{4}{|c|}{ Pr of WAT } \\
\hline Pr1 & It is the questionnaire with concepts on one side and corresponding complements on the other side. & 2 & 20 \\
\hline $\operatorname{Pr} 2$ & It is the questionnaire which investigates associations in students' minds for a given word or concept. & 1 & 10 \\
\hline Pr3 & I do not know. & 7 & 70 \\
\hline Subtotal & & 10 & 100 \\
\hline \multicolumn{4}{|c|}{ IS results of WAT } \\
\hline IS1 & Results are interpreted and scored according to every correct match. & 2 & 20 \\
\hline IS2 & I do not know & 8 & 80 \\
\hline Subtotal & & 10 & 100 \\
\hline
\end{tabular}

In parallel with Table 6, competences of prospective science teachers for WATs are given in Figure 6. As seen in Figure 6 , according to the prospective science teachers, they have $10 \%$ of strong competence and $90 \%$ of incompetence for DF, which is the first category of WATs. As for P, which is the second category under WAT, they have $10 \%$ strong competence and $90 \%$ incompetence. Thirdly, participants have $10 \%$ weak proficiency and $90 \%$ incompetence for Pr of WAT. Lastly in IS, the last category of WAT, it was found out that all of the participants have $100 \%$ incompetence.

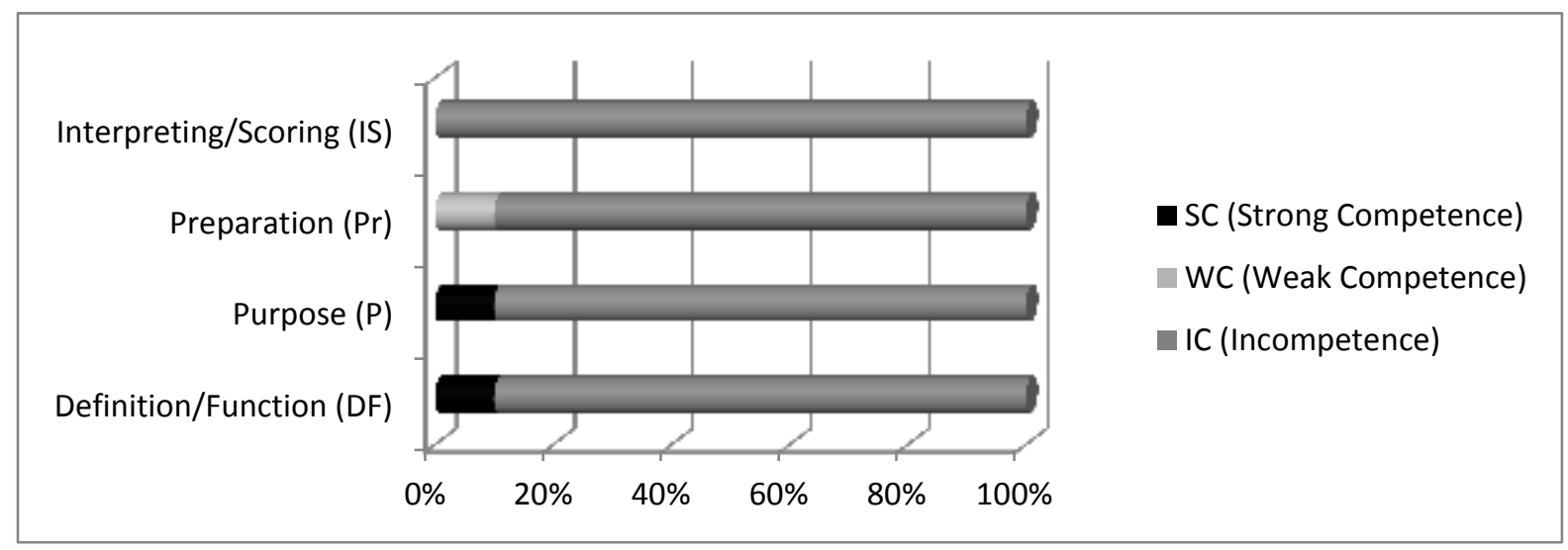

Figure 6. Competence levels of PSTs for WATs

\subsection{Perceptions and Competences of PSTs Related to Interview (I)}

The first category consists of DF of I with 10 codes under it as DF1 to DF10. PSTs placed the most focus on DF4 and DF10 with $30 \%$. The second category includes $\mathrm{P}$ of I and 4 codes are located under this category as P1 to P4. Prospective science teachers were found to have the most emphasis on P4 with 37,5\%, followed by P1 and P2, respectively at $25 \%$. The third category consists of Pr of I and under this category are 3 codes as Pr1 to Pr3. Prospective science teachers were found to have the most emphasis on Pr3 with 50\%, followed by $\operatorname{Pr} 1$ at 41,67\%. The fourth category 
is about IS results of I and under this category there are 6 codes from IS1 to IS6. Prospective science teachers were found to have the most emphasis on IS2 with 46,67\%, followed by IS1 with $20 \%$.

Table 7. Perceptions of PSTs related to I

\begin{tabular}{|c|c|c|c|}
\hline Codes & DF of I & $\mathrm{f}$ & $\%$ \\
\hline DF1 & It is a kind of oral examination. & 6 & 30,00 \\
\hline DF2 & Is an approach that we use to measure the knowledge of students. & 1 & 5,00 \\
\hline DF3 & It is an approach used in business negotiations. & 1 & 5,00 \\
\hline DF4 & Is an approach that we use to get to know the students. & 1 & 5,00 \\
\hline DF5 & It is an approach to measure the students' ability to express themselves. & 1 & 5,00 \\
\hline DF6 & It is the process by which students and teachers mutually express their respective opinions. & 1 & 5,00 \\
\hline DF7 & It is not a measurement and evaluation tool. & 1 & 5,00 \\
\hline DF8 & It is an approach based on face to face conversation with non-active students. & 1 & 5,00 \\
\hline DF9 & It is a data collection tool. & 1 & 5,00 \\
\hline DF10 & I do not know. & 6 & 30,00 \\
\hline Subtotal & & 20 & 100 \\
\hline \multicolumn{4}{|c|}{$\mathrm{P}$ of I } \\
\hline $\mathrm{P} 1$ & To measure the student's knowledge & 4 & 25,00 \\
\hline $\mathrm{P} 2$ & To measure speech and self-expression skills. & 4 & 25,00 \\
\hline P3 & To measure readiness of students. & 2 & 12,50 \\
\hline $\mathrm{P} 4$ & I do not know. & 6 & 37,50 \\
\hline Subtotal & & 16 & 100 \\
\hline \multicolumn{4}{|c|}{ Pr of I } \\
\hline Pr1 & It is an approach in which certain questions are prepared and implemented. & 5 & 41,67 \\
\hline $\operatorname{Pr} 2$ & It is prepared in order to talk with students and take notes about a certain subject. & 1 & 8,33 \\
\hline $\operatorname{Pr} 3$ & I do not know. & 6 & 50,00 \\
\hline Subtotal & & 12 & 100 \\
\hline \multicolumn{4}{|c|}{ IS results of I } \\
\hline IS1 & Interpretation and scoring is done according to the correct responses of students. & 3 & 20,00 \\
\hline IS2 & $\begin{array}{l}\text { As in written exams, results are interpreted and scored according to the prepared answer } \\
\text { key. }\end{array}$ & 2 & 13,33 \\
\hline IS3 & Student responses are recorded and then examined in detail for scoring and interpretation. & 1 & 6,67 \\
\hline IS4 & Short notes are taken and then scoring and interpretation is done by examining these notes. & 1 & 6,67 \\
\hline IS5 & Results are scored and interpreted based on pre-determined criteria. & 1 & 6,67 \\
\hline IS6 & I do not know. & 7 & 46,67 \\
\hline Subtotal & & 15 & 100 \\
\hline
\end{tabular}

In parallel with Table 7, competences of PSTs for interview are given in Figure 7. As seen in Figure 7, according to the prospective science teachers, they have $20 \%$ of strong competence, $60 \%$ of weak competence and $20 \%$ of incompetence for DF, which is the first category of interview. As for P, which is the second category under interview, they have $20 \%$ strong competence, $30 \%$ weak competence and $50 \%$ incompetence. Thirdly, participants have $60 \%$ weak competence and $40 \%$ incompetence for Pr of I. Lastly in IS, the last category of I, it was found out that participants have $30 \%$ of weak competence and $70 \%$ of incompetence.

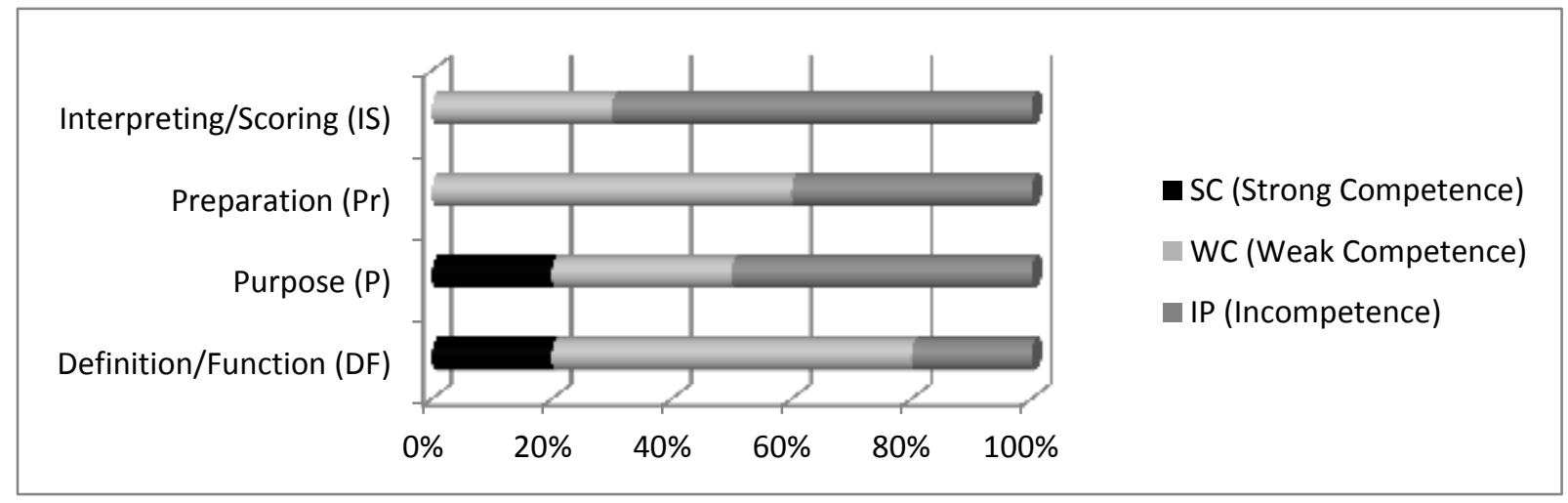

Figure 7. Competence levels of PSTs for I

\subsection{Perceptions and Competences of PSTs Related to Observation $(O)$}

The first category consists of DF of O with 8 codes under it as DF1 to DF8. PSTs placed the most focus on DF8 with $33,33 \%$, followed by DF1 at $20 \%$. The second category includes $\mathrm{P}$ of $\mathrm{O}$ and 7 codes are located under this category as P1 to P7. Prospective science teachers were found to have the most emphasis on P7 with 42,86\%, followed by P1 at $21,43 \%$. The third category consists of $\operatorname{Pr}$ of $\mathrm{O}$ and under this category are 6 codes as Pr1 to Pr6. Prospective science 
teachers were found to have the most emphasis on $\operatorname{Pr} 6$ with $61,54 \%$, followed by $\operatorname{Pr} 1, \operatorname{Pr} 2, \operatorname{Pr} 3, \operatorname{Pr} 4$, and $\operatorname{Pr} 5$, respectively at $7,69 \%$. The fourth category is about IS results of $\mathrm{O}$ and under this category there are 3 codes from IS 1 to IS3. Prospective science teachers were found to have the most emphasis on IS3 with $81,82 \%$, followed by IS1 and IS2 with $9,09 \%$.

Table 8. Perceptions of PSTs related to $\mathrm{O}$

\begin{tabular}{|c|c|c|c|}
\hline Codes & DF of O & $\mathrm{f}$ & $\%$ \\
\hline DF1 & It is a research and investigation. & 3 & 20,00 \\
\hline $\mathrm{DF} 2$ & It is an information acquisition process about students by monitoring them. & 2 & 13,33 \\
\hline DF3 & Results of observation carried out while students are involved in experiments. & 1 & 6,67 \\
\hline DF4 & Students' observing and reporting what they understand at the end of the course. & 1 & 6,67 \\
\hline DF5 & It is the approach that allows generating observation forms containing specific criteria and evaluating students. & 1 & 6,67 \\
\hline DF6 & It is the process of gathering information on a given topic or task assigned to students. & 1 & 6,67 \\
\hline DF7 & It an approach used to determine readiness of students. & 1 & 6,67 \\
\hline DF8 & I do not know. & 5 & 33,33 \\
\hline \multicolumn{2}{|c|}{ Subtotal } & 15 & 100 \\
\hline \multicolumn{4}{|c|}{$\mathrm{P}$ of $\mathrm{O}$} \\
\hline P1 & It is about recognizing students. & 3 & 21,43 \\
\hline $\mathrm{P} 2$ & It is about measuring the attention of students. & 1 & 7,14 \\
\hline P3 & It is about observing the participation of students in the course. & 1 & 7,14 \\
\hline $\mathrm{P} 4$ & It is about ensuring the monitoring of student progress in the process. & 1 & 7,14 \\
\hline P5 & It is about determining and observing social relations of students. & 1 & 7,14 \\
\hline P6 & It is about observing the students that are passive and introvert in the course in different environments. & 1 & 7.14 \\
\hline P7 & I do not know. & 6 & 42,86 \\
\hline \multicolumn{2}{|c|}{ Subtotal } & 14 & 100 \\
\hline \multicolumn{4}{|c|}{ Pr of $\mathrm{O}$} \\
\hline Pr1 & It is prepared by taking students' observations in writing during an experiment or event (trips and observation). & 1 & 7,69 \\
\hline Pr2 & It is prepared by taking written notes on students' performance in the classroom. & 1 & 7,69 \\
\hline Pr3 & Students should not be made aware observed. & 1 & 7,69 \\
\hline $\operatorname{Pr} 4$ & Based on the questions prepared by the teacher, an observation is prepared and made. & 1 & 7,69 \\
\hline Pr5 & It is prepared as a form containing certain criteria. & 1 & 7,69 \\
\hline Pr6 & I do not know. & 8 & 61,54 \\
\hline \multicolumn{2}{|c|}{ Subtotal } & 13 & 100 \\
\hline \multicolumn{4}{|c|}{ IS results of $\mathrm{O}$} \\
\hline IS1 & Results are scored and interpreted on pre-determined criteria. & 1 & 9,09 \\
\hline IS2 & $\begin{array}{l}\text { Students are observed in the classroom, and they are scored and interpreted accordingly by giving plus or minus } \\
\text { points. }\end{array}$ & 1 & 9,09 \\
\hline IS3 & I do not know. & 9 & 81,82 \\
\hline \multicolumn{2}{|c|}{ Subtotal } & 11 & 100 \\
\hline
\end{tabular}

In parallel with Table 8, competences of prospective science teachers for Observation $(\mathrm{O})$ are given in Figure 8 . As seen in Figure 8, according to the prospective science teachers, they have $10 \%$ of strong competence, $30 \%$ of weak competence and $60 \%$ of incompetence for DF, which is the first category of observation. As for $\mathrm{P}$, which is the second category under observation, they have $10 \%$ strong competence, $30 \%$ weak competence and $60 \%$ incompetence. Thirdly, participants have $30 \%$ weak competence and $70 \%$ incompetence for Pr of O. Lastly in IS, the last category of O, it was found out that participants have $20 \%$ of weak competence and $80 \%$ of incompetence.

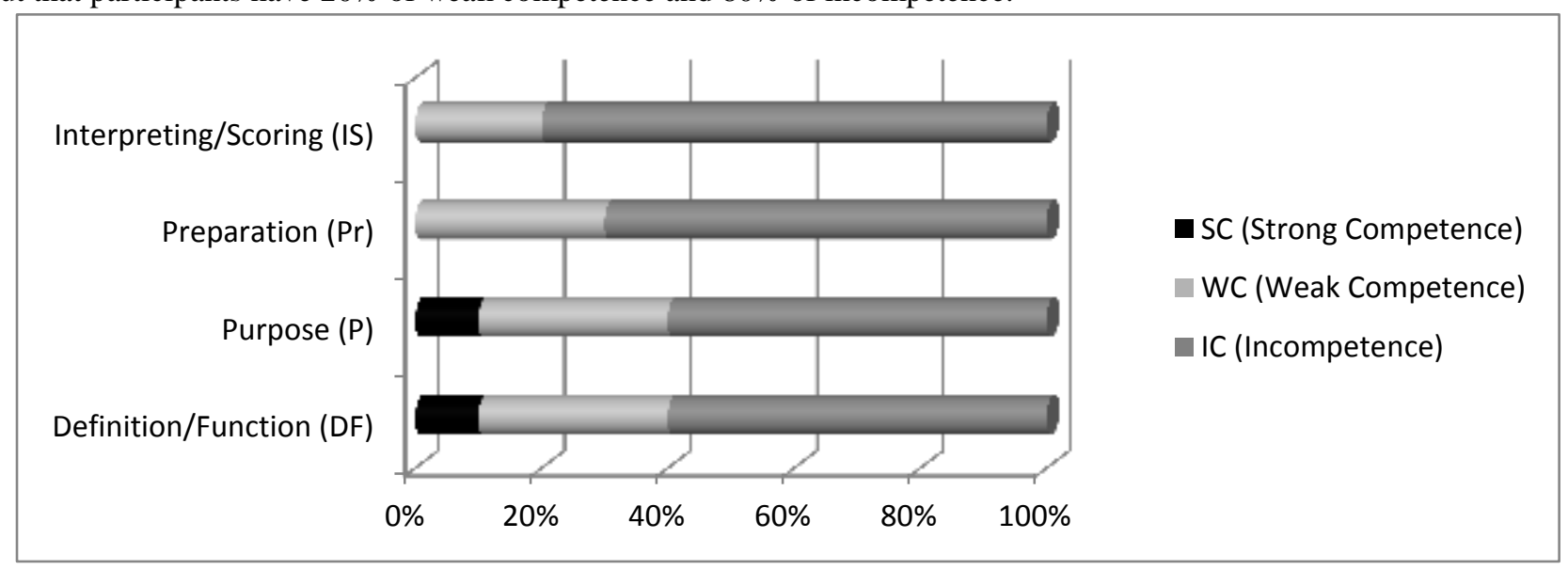

Figure 8. Competence levels of PSTs for O 


\section{Conclusions and Discussions}

In this study, prospective science teachers' perceptions and thus competences related to formative assessment approaches were investigated. It was found out that PSTs do not have a far-fetching perception and interpretation for each of the mentioned formative assessment approaches (see Table 1 through Table 8) and they have inadequate levels of competence as well (see Figure 1 through Figure 8). In conclusion, PSTs' qualifications for all of those formative assessment approaches are given below in Figure 9. As can be seen from Figure 9, although PSTs have knowledge, though little, about function and definition of the formative assessment approaches in this study (12\% competence), they seriously lack knowledge related to the purpose of such approaches ( $7 \%$ competence), how to prepare them as an assessment tool (3\% competence) and interpretation and scoring of the results obtained (2\%). In this study, the results seem to be supported by Şaşmaz-Ören, Ormanc1 \& Evrekli (2014), suggesting that prospective science teachers have moderate levels of self-sufficiency related to alternative assessment approaches. Besides, the results of this study is similar to Sağlam-Arslan, Devecioğlu-Kaymakçı \& Arslan (2009) and Şener-Çoruhlu, Er-Nas \& Çepni (2009), which carried out research on science-technology teachers, found out that teachers cannot use this kind of approach effectively and among other problems teachers do not have sufficient knowledge and skills about this type of assessment and evaluation approaches.

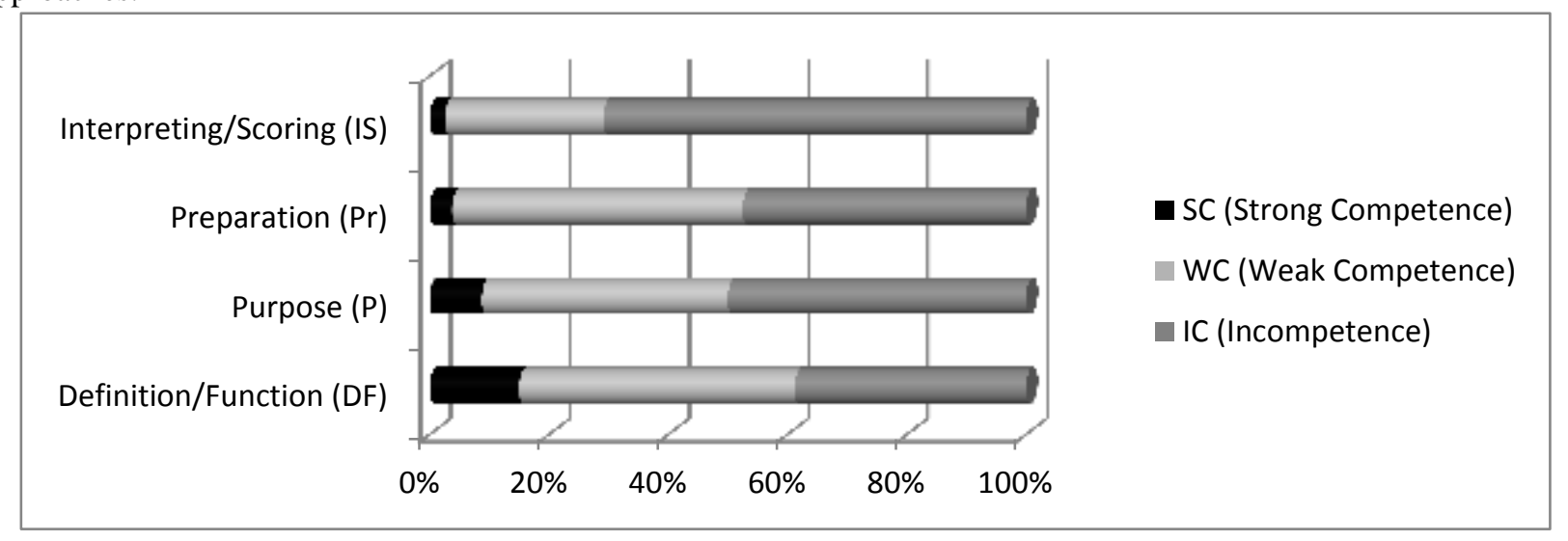

Figure 9. Competence levels of PSTs for FAA

It is understood from this study that prospective science teachers will face difficulties in using formative assessment approaches in the future once they become in-service teachers. Furthermore, the study suggests that prospective science teachers do get adequate levels of education on purposes to use formative assessment approaches for, how to prepare them or interpret the results. This shows that education faculties have serious shortcomings in assessment and measurement. Moreover, in teacher training programs, more emphasis should be made to PSTs' literacy of assessment and pre-service teachers should be trained accordingly. Thus, prospective teachers will be able to both choose and apply the assessment approaches that are appropriate to support student learning (Siegel \& Wissehr, 2011). In addition, it is recommended that education faculties offer more practical assessment and measurement activities and elective courses rather theoretical courses in the context of science education (Şaşmaz-Ören, Ormanc1 \& Evrekli, 2014). It is thought that qualifications and development of PSTs can be promoted if they are prepared for the real school and classroom environment and climate, and if they apply these formative assessment approaches in the long term. In this way, prospective teachers will have increased levels of knowledge on assessment and formative assessment approach in particular, and their self-confidence and self-sufficiency will develop accordingly (Şaşmaz-Ören, Ormancı \& Evrekli, 2014; Yılmaz-Tüzün, 2008). Lastly, contribution will be made to solving the problem if this type of formative assessment approach is used frequently and effectively in science education from the first school to tertiary education and students get accustomed to that approach.

\section{References}

Abell, S. K., \& Siegel, M. A. (2011). Assessment literacy: What science teachers need to know and be able to do. In D. Corrigan, J. Dillon \& R. Gunstone (Edits.). The professional knowledge base of science teaching (pp.205-221). Netherlands: Springer.

HEC (Higher Education Council) (2007). Education faculty teacher training programs. [Online] http://www.yok.gov.tr/documents/10279/30217/E\%C4\%9E\%C4\%B0T\%C4\%B0M+FAK\%C3\%9CLTES\%C4\%B0 $\% 20 \% \mathrm{C} 3 \% 96 \% \mathrm{C} 4 \% 9$ ERETMEN+YET\%C $4 \%$ B0\%C5\%9ET\%C4\%B0RME+L\%C4\%B0SANS+PROGRAMLAR I.pdf/054dfc9e-a753-42e6-a8ad-674180d6e382.pdf, retrieved January, 15, 2017

Lyon, E. G. (2013). Learning to assess science in linguistically diverse classrooms: tracking growth in secondary 
science pre-service teachers' assessment expertise. Science Education, 97(3), 442-467. https://doi.org/10.1002/sce.21059

McMillan, J. H., \& Schumacher, S. (2010). Research in education: Evidence-based inquiry ( $^{\text {th }}$ Edition). Boston: Pearson Education.

Meriam, S. B. (1998). Qualitative research and case study applications in education: Revised and expanded form case study research in education. San Francisco: Jossey-Bass Publishers.

Mertler, C. A., \& Campbell, C. (2005, April). Measuring teachers' knowledge and application of classroom assessment concepts: Development of the assessment literacy inventory. Paper presented at the annual meeting of the American Educational Research Association, Montreal, Quebec, Canada, Google scholar, retrieved January, 15, 2017.

MoNE (Minister of National Education) (2013). Science Curriculum grade 3. 4.5.6. 7 and 8. Ankara: Devlet Kitapları Müdürlüğ̈̈.

Sağlam-Arslan, A., Devecioğlu-Kaymakçı, Y., \& Arslan, S. (2009). Problems concerning alternative evaluation methods: The case of science and technology teachers. Ondokuz Maylz University Journal of Faculty of Education, 28, 1-12.

Şaşmaz-Ören, F., Ormanc1, Ü., \& Evrekli, E. (2014). The alternative assessment-evaluation approaches preferred by pre-service teachers and their self-efficacy toward these approaches. Education and Science, 39(173), 1-15.

Şener-Çoruhlu, T., Er-Nas, S., \& Çepni, S. (2009). Problems facing science and technology teachers using alternative assessment technics: Trabzon sample. Yüzüncü Yll University Journal of Faculty of Education, 6(1), 122-141.

Shepart, L. A. (2000). The role of assessment in a learning culture. Educational Researcher, 29(7), 4-14. https://doi.org/10.3102/0013189X029007004

Siegel, M. A., \& Wissehr, C. (2011). Preparing for the plunge: Pre-service teachers' assessment literacy. Journal of Science Teacher Education, 22, 371-391. https://doi.org/10.1007/s10972-011-9231-6

Türnüklü, A. (2000). A qualitative research technique that can be effectively used in educational science researches: Interview. Educational Administration: Theory and Practice, 24, 543-559.

Yllmaz-Tüzün, O. (2008). Pre-service elementary teachers' beliefs about science teaching. Journal of Science Teacher Education, 19(2), 183-204. https://doi.org/10.1007/s10972-007-9084-1

\section{Copyrights}

Copyright for this article is retained by the author(s), with first publication rights granted to the journal.

This is an open-access article distributed under the terms and conditions of the Creative Commons Attribution license which permits unrestricted use, distribution, and reproduction in any medium, provided the original work is properly cited. 